Jap. J. M. Sc. \& Biol., 13, 207-212, 1960

\title{
SURVIVAL OF ANCYLOSTOMA DUODENALE IN VITRO
}

\author{
KAZUO YASURAOKA, YUKIO HOSAKA AND KIYOKO OGAWA \\ Department of Parasitology, National Institute of Health, Tokyo
}

(Received: November 11th, 1960)

The lack of knowledge concerning the metabolism and general physiology of adult hookworms is mainly due to difficulties in keeping them alive for prolonged observation outside the body of their host. In a previous paper (Komiya et al., 1956), it was shown that the adult of dog hookworm, A. caninum, can be kept alive for 6 weeks in the case of male and for 12 weeks in the case of female worms in dog serum. Since the filariform larvae of human hookworm, $A$. duodenale, were found to develop to the adult stage in the dog body experimentally (Yoshida et al., 1959), the following experiment was conducted to maintain this adult worm in vitro. On the other hand, in an attempt to know whether eggs laid in vitro could be developed to filariform larvae, the cultivation of the free-living stages was performed in the absence of living bacteria.

\section{MATERIALS AND METHODS}

Two dogs were infected with 840 specimens of the filariform larvae of $A$. duodenale cutaneausly or per os and 22 days after infection each dog was dissected and worms were removed from its small intestine safely by the use of dissecting needles. The infectivity of the larvae to the dog is given in Table 1 , and the average body length of worms removed measured $4.5 \mathrm{~mm}(4.0-5.5 \mathrm{~mm})$ in the

Table 1. Infectivity of Ancylostoma duodenale in dog*

\begin{tabular}{ccccc} 
& No. of larvae & Route & $\begin{array}{c}\text { No. of worms } \\
\text { obtained }\end{array}$ & Infection rate \\
\hline Dog I & 840 & Skin & 155 & $18.5 \%$ \\
Dog II & 840 & Mouth & $40 \begin{array}{c}\text { o } \\
\text { \% } 21\end{array}$ & $4.8 \%$ \\
\hline
\end{tabular}

* Examination was made 22 days after infection.

male and $5.0 \mathrm{~mm}(4.4-5.7 \mathrm{~mm})$ in the female. For external sterilization, the worms were washed in $40 \mathrm{cc}$ Petri dishes in 5 changes of sterile Tyrode solutions incorporated with antibiotics in a high concentration. Then two couples of worms were transferred to each Carrel flask $(3.5 \mathrm{~cm}$ diam.) containing $4.8 \mathrm{cc}$ of serum, to which had been added previously 50 units Penicillin G potassium, $100 \mu \mathrm{g}$ Dihydrostreptomycin sulfate and $50 \mu \mathrm{g}$ of dehydroacetic acid per cc medium, and three flasks were used for each medium. The medium was changed completely after every 2 days. As the criterion of survival, motility of worms was tested at intervals of 24 hours under an inverted dissecting microscope of low power. Human serum used in this experiment was

安羅岡一男・保阪幸男・小川清子 (国立予防衛生研究所寄生虫部) 
obtained from a blood bank, and horse serum from the carotid of a house in this institute. Chick embryo extract (CEE) was prepared by the same process as detailed in Weinstein's paper (1953). All experiments were conducted under aseptic conditions.

\section{RESULTS}

Survival Time: Fig. 1 demonstrates the survival of worms in human and horse sera. In human serum the longest time of survival was 102 days in the male and 140 days in the female, whereas in horse serum it was 40 days in the male and 61 days in the female. Thus the survival time of worms in human serum was longer than that in horse serum.

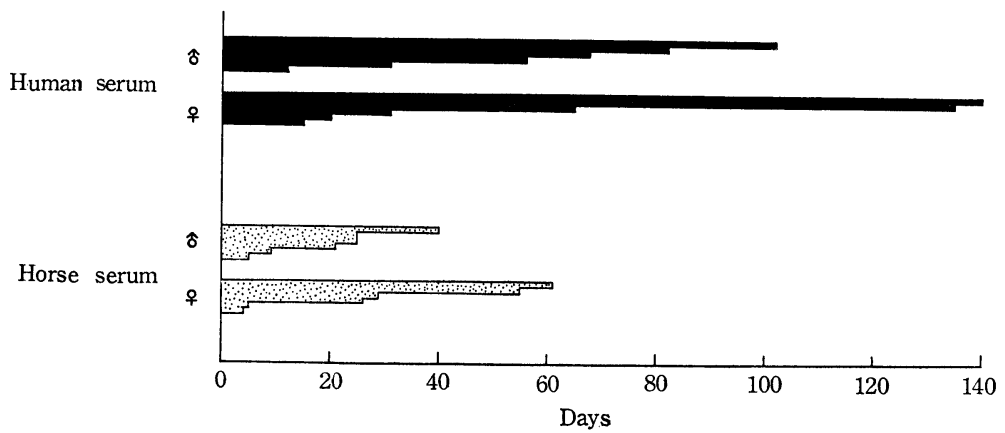

Fig. 1. The length of survival of Ancylostoma duodenale in human and borse sera.

Increase in Body Length: As already stated above, the initial body length of worms was $4.5 \mathrm{~mm}(4.0-5.5)$ in the male and $5.0 \mathrm{~mm}(4.4-5.7)$ in the female. During the course of the experiment the body length of worms was measured whenever they were found dead and the number of worms measuring longer than the longest one in the initial body-length estimation was 4 out of 6 males and all of the 6 females as shown in Table 2. It may be suggested that a considerable increase in their body length took plase in vitro.

Copulation: During the first 3 weeks of survival time, copulation was found several times only in human serum.

Egg Laying: In the above experiment the medium was removed after every 2 days by transfer of worms, and eggs laid in the medium were examined at each transfer. Egg laying was found only in human serum, and the results are summarized in Table 3. Only abnormal eggs which were assumed to be unfertilized eggs were found during 10 days from the initial day. Numerous embryonated eggs and hatched larvae, however, were found later for a period extending from 13 days through 33 days, and after 8 weeks they disappeared completely.

Cultivation of Eggs Laid in vitro under Aseptic Condition: To know whether eggs laid in vitro could be developed to filariform larvae, the cultivation was made by using procedures essentially similar to those of Weinstein (1953). Several hundred eggs having been laid 20-21 days and 30-31 days later, respectively, were put into test tubes of $1.3 \mathrm{~cm}$ in diameter and $15 \mathrm{~cm}$ in length containing $5 \mathrm{cc}$ of $\mathrm{CEE}_{50}$ and incubated at 
Table 2. Increase in the body length of worms in the course of keeping them in human serum

\begin{tabular}{ccc}
\hline \multirow{2}{*}{ Days maintained } & \multicolumn{2}{c}{ Body length $(\mathrm{mm})$} \\
\cline { 2 - 3 } & \multicolumn{1}{c}{$\hat{\mathrm{o}}$} & \multicolumn{1}{c}{+} \\
\hline 0 & $4.5(4.0-5.5)$ & $5.0(4.4-5.7)$ \\
12 & 7.1 & 8.2 \\
15 & & 8.4 \\
31 & 5.0 & 12.0 \\
50 & 5.5 & \\
67 & 8.5 & 9.8 \\
83 & 6.5 & \\
102 & 7.1 & \multicolumn{2}{|c}{} \\
135 & & 8.6 \\
140 & & 10.7 \\
\hline
\end{tabular}

Table 3. Egg laying of Ancylostoma duodeuale living in human serum

\begin{tabular}{|c|c|c|c|c|}
\hline Days & No. of eggs & $\begin{array}{l}\text { No. of } \\
\text { embryonated } \\
\text { eggs }\end{array}$ & $\begin{array}{l}\text { No. of } \\
\text { hatched } \\
\text { larvae }\end{array}$ & $\begin{array}{l}\text { No. of eggs } \\
\text { per female } \\
\text { per day }\end{array}$ \\
\hline $3-4$ & 100 & 0 & 0 & 17 \\
\hline $5-6$ & 380 & 0 & 0 & 63 \\
\hline $7-8$ & 180 & 0 & 0 & 30 \\
\hline $9-10$ & 40 & 0 & 0 & 7 \\
\hline $11-12$ & 0 & 0 & 0 & 0 \\
\hline 13-14 & 250 & 10 & 0 & 63 \\
\hline 15 & 30 & 0 & 0 & 15 \\
\hline $16-17$ & 1,860 & 1,240 & 320 & 465 \\
\hline $18-19$ & 5,700 & 3,130 & 1,240 & 1,425 \\
\hline \multicolumn{5}{|l|}{$20-21^{*}$} \\
\hline $22-23$ & 4,960 & 4,170 & 80 & 1,240 \\
\hline $24-25$ & 4,720 & 1,440 & 1,900 & 1,180 \\
\hline $26-27$ & 6,150 & 4,640 & 200 & 1,538 \\
\hline $28-29$ & 2,260 & 1,130 & 260 & 565 \\
\hline \multicolumn{5}{|l|}{$30-31^{*}$} \\
\hline $32-33$ & 1,140 & 30 & 160 & 570 \\
\hline 34-35 & 130 & 0 & 0 & 65 \\
\hline $36-38$ & 210 & 0 & 0 & 70 \\
\hline $39-40$ & 10 & 0 & 0 & 3 \\
\hline $41-54$ & 0 & 0 & 0 & 0 \\
\hline $55-56$ & 0 & 0 & 6 & 2 \\
\hline $57-140$ & 0 & 0 & 0 & 0 \\
\hline
\end{tabular}

* The number of eggs was not examined in this duration because of using for larval cultivation. 


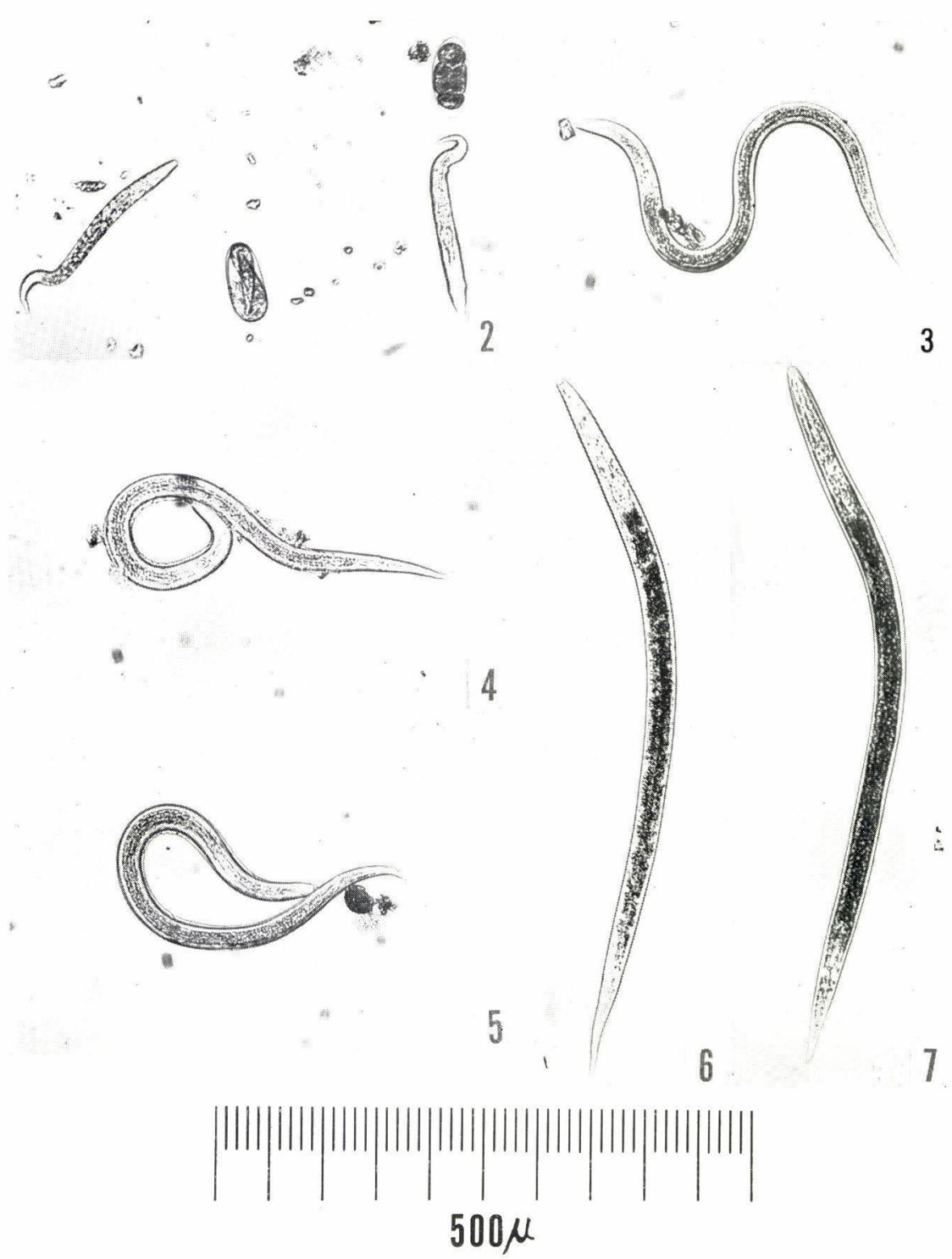

Fig. 2. Eggs laid and hatched larvae in human serum.

Fig. 3 7. Filariform larvae which had developed in $\mathrm{CEE}_{\overline{5} 0}$.

$28^{\circ} \mathrm{C}$. The medium was renewed after every 48 hours. As seen in Figs. 3-7, filariform larvae measuring $0.666 \mathrm{~mm}(0.635-0.715 \mathrm{~mm})$ in length were obtained after 8 days. Test for bacterial contaminants was made at the termination of culture by using fluid thioglycolacid medium, and all media had no associated living bacteria.

\section{DISCUSSION}

In testing the anthelmintic value of a drug for ancylostomiasis, preliminary in vitro 
experiments are considered to be an essential step and for such a purpose the dog hookworm, A. caninum, is usually applied because of facility of obtaining it. It is, however, doubtful whether the result obtained with the dog hookworm is applicable to the human hookworm. As already mentioned above, the fact that the human hookworm, A duodenale, obtained from the experimentally infected dog could survive for more than 4 months in human serum suggests that $A$. duodenale could be applied readily for testing the anthelmintic value of a drug in vitro instead of $A$. caninum.

The survival time of worms in human serum was considerably longer than that in horse serum (Fig. 1). In A. caninum, also, the survival time in dog serum was longer than those in horse and cattle sera (Yasuraoka et al., 1958). The fact that the longest survival time was found in the serum of their native hosts has an interesting bearing on their host-parasite relationship. In other words, a factor influencing the host-parasite relationship appears to exist in the serum of the host. It seems possible, therefore, that the comparative study of the serum on both normal and abnormal hosts has an important role in inquiring into the mechanism of this relationship.

In vitro cultivation of the free-living stage of nematodes under aseptic conditions is hindered seriously by the presence of contaminating microorganisms. Numerous attempts have been made to sterilize the materials by the use of bactericides such as antibiotics, White's, Milton's, Laboraque solutions and so forth (McCoy, 1929 ; Glaser et al., 1938, 1940 ; Weller, 1943 ; Lawrence, 1948 ; Epps et al., 1950 ; Fairbairn, 1950). In these media, however, the sterilized materials have been obtained in conditions more or less harmful to the organisms. In the present experiment the aseptic eggs were obtained by the omission of bactericides and without any harmful effect by culturing the adult worms in flasks under aseptic conditions, and almost all of them developed to an infective stage. Such a procedure would prove useful when other nematode eggs are to be obtained in aseptic conditions.

It may be given as a conclusion that human serum is a comparatively sufficient medium for maintaining $A$. duodenale in vitro because of (1) the worms survived for over 4 months, (2) the worms increased in their body-length, (3) copulation and egg-laying took place and (4) the eggs laid in vitro developed to an infective stage.

\section{SUMMARY}

The human hookworm, A. duodenale, obtained from an experimentally infected dog could survive for more than 4 months in human serum in vitro. Eggs laid therein developed to filariform larvae in $\mathrm{CEE}_{50}$ under aseptic conditions.

The authors are greatly indebted to Dr. Y. Komiya, Chief of Department of Parasitology, the National Institute of Health of Japan, for his valuable advices and frequent encouragements.

\section{REFERENCES}

Epps, W., Weiner, M. \& Bueding, E. (1950): Production of steam volatile acids by bacteriafree Ascaris lumbricoides. J. Infect. Dis., 87, 149-151.

FAIRBAIRN, D. \& REESAL, M. R. (1950): Complete elimination of microorganisms from an intestinal parasite (Ascaris lumbricoides). Science, 112, 792-793.

Glaser, R. W. \& Stool, N. R. (1938): Sterile culture of the free living stages of the sheep stomach worm, Haemonchus contortus. Parasitol., 30, 324-332.

GlaseR, R. W. \& StOOL, N. R. (1940): Exsheathing and sterilizing infective nematole larvae. 
J. Parasitol., 26, 87-94.

Komiya, Y., YASURAOKA, K. \& SATO, A. (1956) : Survival of Ancylostoma caninum in vitro (1). Jap. J. M. Sc. \& Biol., 9, 283-292.

LAWRENCE, J.J. (1948): The cultivation of the free-living stages of the hookworm, Ancylostoma brazilienze de faria, under aseptic conditions. Australian J. Exper. Biol. \& Med., 26, 1-8.

McCoy, O. R. (1929): The suitability of various bacteria as food for hookworm larvae. Am. ${ }^{\overline{ }} \mathrm{J}$. Hyg., 10, 140-156.

Weller, T. H. (1943) : The development of the larvae of Trichinella spiralis in roller tube tissue cultures. Am. J. Path., 19, 503-515.

WeInstein, P. P. (1953): The cultivation of the free-living stages of hookworms in the absence of living bacteria. Am. J. Hyg., 58, 352-376.

YASURAOKA, K., SATO, A. \& HoSAKA, Y. (1958): Survival of Ancylostoma caninum in vitro (2). Jap. J. Parasitol., 7, 40 (text in Japanese).

YoshidA, Y. \& OKANO, K. (1959): On the development of Ancylostoma duodenale in the unsuitable host, dogs and the infection with the larvae of $A$. doudenale obtained from these dogs, to the human body. Jap. J. Parasitol., 8, 386-387 (text in Japanese). 